\begin{tabular}{l|lll|}
\hline History Article & Received: Maret 2020 & Approved: Maret 2020 & Published: Maret 2020 \\
\hline
\end{tabular}

\title{
PENGARUH PEMBERIAN VARIASI Azolla microphylla PADA PAKAN TERHADAP PERTUMBUHAN IKAN BAUNG SEBAGAI SUMBER BELAJAR BIOLOGI
}

\author{
Untung Tri Rahayu ${ }^{1}$, Handoko Santoso ${ }^{2}$, Achyani ${ }^{3}$
}

${ }^{123}$ Program Pascasarjana Pendidikan Biologi, Universitas Muhammadiyah Metro Email: trirahayu995@gmail.com ${ }^{1)}$, handoko.umm@gmail.com ${ }^{2)}$, acysbd@gmail.com ${ }^{3)}$

\begin{abstract}
Abstrak
Penelitian ini bertujuan untuk mengetahui pengaruh pemberian variasi Azolla microphylla pada pakan terhadap pertumbuhan ikan baung. Metode yang digunakan dalam penelitian ini adalah metode eksperimen menggunakan Rancangan Acak Lengkap (RAL). Perlakuan dalam penelitian ini adalah pemberian variasi Azolla pada pakan. Pakan dengan Variasi Azolla 1000g, Azolla 2000g dan Azolla 3000g. Parameter yang diukur dalam penelitian ini meliputi laju pertumbuhan bobot ikan, panjang ikan, dengan data pendukung berupa kelulushidupan ikan, dan kualitas air pada media pemeliharaan. Data utama kemuadian ditabulasi dan dianalisis menggunakan aplikasi SPSS yang meliputi Analisis Ragam One Way Anava. Penelitian ini juga menggunakan uji laboratorium berupa uji kandungan protein pada pakan ikan baung yang di gunakan selama pengamatan. Pengujian kandungan protein pada pakan dilakukan di Laboratorium Analisis Politeknik Negeri Lampung. Berdasarkan Hasil analisis ANOVA menunjukkan bahwa pemberian variasi Azolla microphylla pada pakan memberikan pengaruh nyata terhadap pertumbuhan bobot dan pertumbuhan panjang ikan baung $(P<0,05)$. Persentase kelangsungan hidup ikan baung selama penelitian mencapai 64,4-66,6\%. Suhu yang didapat selama penelitian berkisar 28,65-29,50C. Sedangkan pH yang didapat selama penelitian berkisar 6,9-7,2.
\end{abstract}

Kata Kunci: Azolla, ikan baung, pakan

\begin{abstract}
This study aims to determine the effect of giving variations of Azolla microphylla in feed on the growth of baung fish. The method used in this study is an experimental method using a Completely Randomized Design (CRD). The treatment in this study was the administration of Azolla variations in feed. Feed with variations of Azolla 1000g, Azolla $2000 \mathrm{~g}$ and Azolla $3000 \mathrm{~g}$. The parameters measured in this study include the growth rate of fish weight, fish length, with supporting data in the form of fish survival, and water quality in the maintenance media. The main data then tabulated and analyzed using the SPSS application which includes Analysis of the One Way Anava Variance. This study also uses a laboratory test in the form of a protein content test in Hemibagrus nemurus feed used during observation. Testing of protein content in feed was carried out at the Lampung State Polytechnic Analysis Laboratory. Based on ANOVA analysis results showed that the provision of Azolla microphylla variations in feed gave a real effect on the growth of weight and length growth of Hemibagrus nemurus $(P<0.05)$. The percentage of survival of baung fish during the study reached 64.4-66,6\%. The temperature obtained during the study ranged from 28.65 to 29.50C. While the $\mathrm{pH}$ obtained during the study ranged from 6.9-7.2.
\end{abstract}

Keywords: Azolla, Hemibagrus nemurus, feed

\section{How to Cite}

Rahayu, Untung Tri, Handoko Santoso, \& Achyani. 2020. Pengaruh Pemberian Variasi Azolla microphylla pada Pakan terhadap Pertumbuhan Ikan Baung sebagai Sumber Belajar Biologi. Biolova 1(2). 150-162. 
Ikan Baung merupakan salah satu komoditas ikan perairan umum yang memiliki potensi untuk dibudidayakan. Selama ini upaya pemenuhan kebutuhan pasar akan ikan Baung kebanyakan mengandalkan hasil tangkapan dari alam, meski pun usaha budidaya pembesaran ikan ini sudah dilakukan dibeberapa tempat, namun hasilnya belum signifikan dalam mencukupi kebutuhan pasar yang sangat besar. Hal ini menyebabkan terjadinya penurunan populasi ikan tersebut. Apabila perilaku usaha penangkapan ikan Baung ini dilakukan terus menerus tanpa adanya upaya peningkatan hasil budidaya, dikhawatirkan keberadaan ikan ini di alam akan terancam. Agar permintaan pasar dapat dipenuhi tanpa mengganggu polupasi ikan di alam, maka perlu dilakukan upaya peningkatan budidaya pembesaran ikan Baung.

Aspek penting dalam pemeliharaan ikan adalah kualitas air. Ada beberapa variabel penting yang berhubungan dengan kualitas air. Variabel-variabel tersebut berhubungan dengan sifat kimia air (kandungan oksigen, karbondioksida, $\mathrm{pH}$, zat-zat beracun dan kekeruhan air). Selain sifat kimia tersebut, air juga memiliki sifat fisika, antara lain yang berhubungan dengan suhu, kekeruhan, dan warna air (Amri dan Khairuman, 2010). Oksigen diperlukan untuk proses respirasi dan metabolisme dalam tubuh ikan untuk aktivitas berenang, pertumbuhan, reproduksi, laju pertumbuhan, dan konversi pakan.
Tabel 1. Nilai Kualitas Air Ikan Baung

\begin{tabular}{l|l}
\hline Parameter & Nilai Kisaran \\
\hline Suhu (oC) & $250-32 \mathrm{o}(\mathrm{a})$ \\
$\mathrm{Ph}$ & $6,5-8(\mathrm{a})$ \\
Oksigen Terlarut (ppm) & $3-8(\mathrm{~b})$ \\
Amoniak (mg/l) & $>0,3(\mathrm{~b})$ \\
\hline
\end{tabular}

Sumber a) Amri dan Khairuman (2010) b) Suhenda dkk, (2010)

Kebutuhan nutrient pada ikan Baung berkiatan erat dengan proses pertumbuhan ikan Baung itu sendiri. Pertumbuhan ikan dipengaruhi oleh beberapa faktor Untuk dapat tumbuh dengan baik, ikan pada umumnya membutuhkan nutrien/gizi yang lengkap. Aspek kebutuhan gizi pada ikan sama dengan makhluk hidup lain, yaitu protein, karbohidrat, lemak, vitamin, dan mineral agar dapat melakukan proses fisiologi dan biokimia selama hidupnya. Penelitian tentang kebutuhan gizi pada ikan Baung masih terbatas, sehingga untuk pendekatan kebutuhan nutrisi pakan disesuaikan dengan ikan lele yang relative lebih lengkap,pada Tebel 2 .

Tabel 2. Kebutuhan nutrisi ikan

Baung dan ikan lele

\begin{tabular}{lll}
\hline Unsur & Ikan Baung & Ikan Lele \\
\hline Protein (\%) & $40^{1)}$ & $25-352)$ \\
Karbohidrat (\%) & $10-152)$ \\
Lemak (\%) & $<202)$ \\
Vitamin (\%) & $12)$ \\
Mineral (\%) & $<12)$ \\
\hline
\end{tabular}

Sumber : 1) Khan et al. (1993)

2) NRC (1993)

Pertumbuhan ikan dipengaruhi oleh faktor internal dan eksternal. Faktor internal yaitu: bobot tubuh, sex, umur, kesuburan, kesehatan, pergerakan, aklimasi, aktivitas biomassa, dan kecukupan oksigen. Sedangkan faktor eksternal terdiri dari faktor abiotik dan faktor biotik. Faktor 
abiotik terdiri dari tekanan, suhu, salinitas, kandungan oksigen air, buangan metabolit $\left(\mathrm{CO}_{2}, \mathrm{NH}_{3}\right), \mathrm{pH}$, cahaya, musim. Faktor nutrisi termasuk factor biotik yang meliputi ketersediaan pakan, komposisi pakan, kecernaan pakan, dan kompetisi pengambilan pakan. Diantara faktorfaktor tersebut, nutrisi merupakan factor pengontrol, dan ukuran ikan mempengaruhi potensi tumbuh suatu individu. Sedangkan suhu air mempengaruhi seluruh kegiatan dan proses kehidupan ikan yang meliputi pernafasan, reproduksi, dan pertumbuhan. Jika suhu air meningkat (sampai batas tertentu), maka laju metabolisme meningkat yang pada gilirannya meningkatkan konsumsi dan pertumbuhan ikan.

Permasalahan yang terjadi pada budidaya ikan yaitu salah satunya adalah pada pakan. Pakan merupakan salah satu penentu keberhasilan kegiatan budidaya. Saat ini pakan komersil yang digunakan sebagai pakan ikan masih relatif mahal, karena sumber protein utama yang sering digunakan dalam industri pellet ikan adalah tepung ikan dan kedele, yang keduanya merupakan komponen termahal dari bahan penyusun ransum. Salah satu cara yang bisa ditempuh dicarikan pakan alternatif yang bermutu tinggi serta mudah dibudidayakan dan tidak memerlukan lahan yang luas. Diharapkan bahan pakan ini dapat mensubstitusi sebagian penggunaan bahan pakan impor yang berarti juga dapat menghemat devisa negara. sehingga dibutuhkan solusi atas permasalahan tersebut, yaitu alternatif bahan baku yang selama ini belum biasa digunakan sebagai pelet komersial tetapi bernilai gizi tinggi dan tidak bersaing degan kebutuhan pangan. Bahan baku tersebut antara lain berasal dari hijauan seperti Azolla microphylla .
Table.3 kandungan Azolla microphylla per 100gram

\begin{tabular}{lc}
\hline Kandungan & Persentase \\
\hline protein kasar & $24-30 \%$ \\
serat kasar & $12,38 \%$ \\
Nitrogen & $43,35 \%$ \\
Abu & $19,33 \%$ \\
Kalsium & $1,64 \%$ \\
Fosfor & $\underline{0,34 \%}$ \\
\hline
\end{tabular}

Sumber : Kumari et.al(2018)

Tanaman Azolla potensial digunakan sebagai pakan karena banyak terdapat di perairan tenang seperti danau, kolam, rawa dan persawahan. Pertumbuhan Azolla dalam waktu 3-4 hari dapat memperbanyak diri menjadi dua kali lipat dari berat segar (Haetami dan Sastrawibawa, 2005). Secara alamiah tanaman Azolla mempunyai keistimewaan mampu mengikat Nitrogen bebas dari udara karena bersimbiosis dengan ganggang biru (Anabaena Azollae), sehingga mengandung protein yang cukup tinggi. Azolla dapat digunakan sebagai pakan sumber protein karena mengadung protein lebih dari $20 \%$, serat kasar 9,1\%, dan mempunyai asam amino yang lengkap. Singh, 1979 (dalam Haetami, dkk (2005:5).

Pakan uji berupa campuran bahan yang terdiri dari bekatul, ikan rucah kering yang di buat tepung, tepung kanji dan Azolla microphylla . Dibuat sesuai dengan perlakuan dan dipersiapkan agar cukup untuk 30 hari pemeliharaan dan disimpan dalam wadah yang kering dan kedap udara untuk menghindari oksidasi serta kerusakan pakan. Azolla microphylla yang digunakan berupa tepung dalam bentuk kering.

\section{METODE}

Penelitian ini dilaksanakan selama 30 hari. Bertempat di Jl. 
Garuda, Rt 29, Rw 07, Rejomulyo 26D, Kec. Metro Selatan. Bahan yang digunakan dalam penelitian ini adalah benih ikan baung dengan ukuran 6-7 $\mathrm{cm}$. Pakan yang di berikan pada pemeliharaan ikan baung selama penelitian adalah jenis pakan buatan yang dibuat dengan tekstur pasta. Wadah yang digunakan adalah ukuran $200 \mathrm{~cm} \times 100 \mathrm{~cm} 3$ dengan tinggi air 20 $\mathrm{cm}$. Alat yang digunakan dalam penelitian ini adalah timbangan digital, penggaris, baskom plastik, kamera, alat tulis. serokan, thermometer dan $\mathrm{pH}$ meter.

Penelitian ini bertujuan untuk mengetahui pengaruh pemberian variasi Azolla microphylla pada pakan terhadap pertumbuhan ikan baung. Metode yang digunakan dalam penelitian ini adalah metode eksperimen menggunakan Rancangan Acak Lengkap (RAL). Terdapat empat perlakuan dengan tiga kali ulanagan. Perlakuan dalam penelitian ini adalah pemberian variasi Azolla pada pakan. Pakan dengan Variasi Azolla 1000 g, Azolla 2000 g dan Azolla 3000 g.

Pelaksanaan penelitian ini ada beberapa tahapan yaitu tahapan persiapan penelitian, tahap pelaksanaan penelitian dan tahap penyususnan Sumber belajar Biologi. Parameter yang diukur dalam penelitian ini meliputi laju pertumbuhan bobot ikan, panjangikan, denagan data pendukung berupa kelulushidupan ikan, dan kualitas air pada media pemeliharaan ikan baung. Selanjutnya data yang telah diperoleh berupa parameter utama kemuadian ditabulasi dan dianalisis menggunakan aplikasi SPSS yang meliputi Analisis Ragam One Way Anava.

Penelitian ini juga menggunakan uji laboratorium berupa uji kandungan protein pada pakan ikan baung yang di gunakan selama pengamatan. Pengujian kandungan protein pada pakan dilakukan di Laboratorium
Analisis Politeknik Negeri Lampung.

\section{HASIL}

\section{Data Hasil Analisis Kandungan Protein Pada Pakan}

Guna mengetahui kandungan protein pada pakan yang akan digunakan Selama penelitian maka diperlukan adanya tes uji kandungan protein pada pakan, berikut hasil uji laboratorium kandungan protein pada pakan disajikan pada Tabel 4.

Tabel 4. Hasil Uji Kandungan Protein pada Pakan yang Digunakan Selama

\begin{tabular}{|c|c|c|c|}
\hline \multicolumn{4}{|c|}{ Penelitian } \\
\hline $\mathrm{N}$ & Kode & Kod & Prote \\
\hline o & $\begin{array}{c}\text { Perlaku } \\
\text { an }\end{array}$ & $\begin{array}{l}\mathrm{e} \\
\text { Samp } \\
\text { el }\end{array}$ & $\begin{array}{l}\text { in } \\
(\%)\end{array}$ \\
\hline 1 & $\mathrm{P}_{0} \mathrm{~V}_{0}$ & $\mathrm{~A}$ & $\begin{array}{c}23,85 \\
\%\end{array}$ \\
\hline 2 & $\mathrm{P}_{0} \mathrm{~V}_{1}$ & B & $\begin{array}{c}29,33 \\
\%\end{array}$ \\
\hline 3 & $\mathrm{P}_{0} \mathrm{~V}_{2}$ & $\mathrm{C}$ & $\begin{array}{c}35,41 \\
\%\end{array}$ \\
\hline 4 & P0V3 & $\mathrm{D}$ & $\begin{array}{c}39,97 \\
\%\end{array}$ \\
\hline
\end{tabular}

Berdasarkan hasil uji kandungan protein pada tabel 1. Komposisi bahan pakan P0V0 (500g bekatul $+500 \mathrm{~g}$ Tepung ikan rucah $+200 \mathrm{~g}$ tepung kanji). Menunjukan hasil kandungan protein sebesar 23,85\%. Pada perlakuan ini menjadi kontrol tidak di tambahkan variasiAzolla. Berdasarkan hasil tersebut perlakuan $\quad \mathrm{P}_{0} \mathrm{~V}_{0}$ menjadi jumlah kandunagan protein yang paling rendah dibandingkan dengan jumlah kadungan protein perlakuan lain. Hal ini dikarenakan sumber protein pada pakan hanya berasal dari tepung ikan rucah.

Komposisi bahan pakan $\mathrm{P}_{0} \mathrm{~V}_{1}$ (500g bekatul $+500 \mathrm{~g}$ Tepung ikan rucah $+200 \mathrm{~g}$ tepung kanji $+1000 \mathrm{gr}$ Tepung Azolla). Menunjukkan hasil kandungan protein sebesar 29,33\%. Berdasarkan hasil tersebut jika 
dibandingkan dengan jumlah kadungan protein perlakuan lain perlakuan ini menjadi jumlah kandunagan protein terendah kedua setelah perlakuan Kontrol namun masih lebih tinggi dibandingkan dnegan perlakuan Kontrol. Hal ini dikarenakan sumber protein pada perlakuan ini tidak hanya berasal dari tepung ikan rucah saja, namun terdapat sumber protein tambahan dari tepung Azolla sebanyak1000g.

Komposisi bahan pakan $\mathrm{P}_{0} \mathrm{~V}_{2}$ (500g bekatul $+500 \mathrm{~g}$ Tepung ikan rucah $+200 \mathrm{~g}$ tepung kanji $+2000 \mathrm{~g}$ Tepung Azolla). Menunjukan hasil kandungan protein sebesar $35,41 \%$.

Berdasarkan hasil tersebut jika dibandingkan dengan jumlah kadungan protein perlakuan lain, perlakuan ini menjadi jumlah kandunagan protein terendah ketiga dari empat perlakuan namun masih lebih tinggi dibandingkan perlakuan $\mathrm{P}_{0} \mathrm{~V}_{0}$ dan $\mathrm{P}_{0} \mathrm{~V}_{1}$. Hal ini dikarenakan sumber protein pada perlakuan ini tidak hanya berasal dari tepung ikan rucah saja, namun terdapat sumber protein tambahan dari tepung Azolla sebanyak $2000 \mathrm{~g}$.

Komposisi bahan pakan $\mathrm{P}_{0} \mathrm{~V}_{3}$ $(500 \mathrm{~g}$ bekatul $+500 \mathrm{~g}$ Tepungikan rucah $+200 \mathrm{~g}$ tepung kanji $+2000 \mathrm{~g}$ Tepung Azolla). Menunjukan hasil kandungan protein sebesar 39,97\%. Berdasarkan hasil tersebut jika dibandingkan dengan jumlah kadungan protein perlakuan lain, perlakuan ini menjadi jumlah kandungan protein tertinggi dibandingkan perlakuan $\mathrm{P}_{0} \mathrm{~V}_{0}, \mathrm{P}_{0} \mathrm{~V}_{1}$ dan $\mathrm{P}_{0} \mathrm{~V}_{2}$. Hal ini dikarenakan sumber protein pada perlakuan ini tidak hanya berasal dari tepung ikan rucah saja, namun terdapat sumber protein tambahan dari tepung Azolla sebanyak $3000 \mathrm{~g}$.
Hasil Analisis Pengujian Hipotesis Pertumbuhan Ikan Baung (Mystus nemurus )

Berikut Tabel hasil analisis pengaruh variasi Azolla pada pertumbuhan obot ikan baung.

\section{ANOVA}

Bobot Ikan Baung

\begin{tabular}{|c|c|c|c|c|c|}
\hline & $\begin{array}{l}\text { Sum of } \\
\text { Squares }\end{array}$ & $\begin{array}{l}\mathrm{D} \\
\mathrm{f}\end{array}$ & $\begin{array}{l}\text { Mean } \\
\text { Square }\end{array}$ & $\mathrm{F}$ & Sig \\
\hline $\begin{array}{l}\text { Between } \\
\text { Groups } \\
\text { Within } \\
\text { Groups } \\
\text { Total }\end{array}$ & $\begin{array}{r}389.221 \\
4.906 \\
394.127\end{array}$ & $\begin{array}{c}8 \\
11\end{array}$ & 129.740 & 211.559 & $\begin{array}{l}.0 \\
00\end{array}$ \\
\hline
\end{tabular}

\section{ANOVA}

Panjang Ikan

\begin{tabular}{|l|r|r|r|r|r|}
\hline & $\begin{array}{l}\text { Sum } \\
\text { of } \\
\text { Squa } \\
\text { res }\end{array}$ & Df & $\begin{array}{l}\text { Mean } \\
\text { Square }\end{array}$ & F & Sig. \\
\hline $\begin{array}{l}\text { Between } \\
\text { Groups } \\
\text { Within } \\
\text { Groups } \\
\text { Total }\end{array}$ & 66.758 & 3 & 22.253 & 124.316 & .000 \\
\hline
\end{tabular}

Berdasarkan tabel output terlihat nilai sig. $0,000<0,05$ yang berarti nilai signifikansinya lebih kecil dari $\alpha=$ 0,05 sehingga $\mathrm{H}_{0}$ ditolak yang artinya terima $\mathrm{H}_{1}$ penambahan variasi Azolla dengan dosis berbeda berpengaruh terhadap pertumbuhan bobot ikan baung. Untuk data hasil analisis bobot ikan baung di sajikan Tabel 4.

Berdasarkan tabel output terlihat nilai sig. $0,000<0,05$ yang berarti nilai signifikansinya lebih kecil dari $\alpha=$ 0,05 sehingga $\mathrm{HO}$ ditolak yang artinya terima $\mathrm{H} 1$ penambahan variasi Azolla dengan dosis berbeda berpengaruh terhadap pertumbuhan panjang ikanbaung.

Berdasarkan tabel output terlihat nilai sig. $0,000<0,05$ yang berarti nilai signifikansinya lebih kecil dari $\alpha=$ 
0,05 sehingga $\mathrm{H} 0$ ditolak yang artinya terima $\mathrm{H} 1$ penambahan variasi Azolla dengan dosis berbeda berpengaruh terhadap pertumbuhan bobot ikan baung. Untuk data hasil analisis bobot ikan baung di sajikan Tabel 4 .

Berdasarkan tabel output terlihat nilai sig. $0,000<0,05$ yang berarti nilai signifikansinya lebih kecil dari $\alpha=$ 0,05 sehingga $\mathrm{H} 0$ ditolak yang artinya terima $\mathrm{H} 1$ penambahan variasi Azolla dengan dosis berbeda berpengaruh terhadap pertumbuhan panjang ikan baung.

\section{Hasil Data Pendukung}

Data Hasil Kualitas Air di sajikan pada tabel 4.

Tabel 4. Pengamatan Kualitas Air Media Pemeliharaan Ikan Baung

\begin{tabular}{lllll}
\multicolumn{2}{l}{ Parameter } & \multicolumn{3}{c}{ Pengamatan } \\
Suhu & 28,65 & 27,45 & 23,2 & 29,5 \\
\hline $\mathrm{Ph}$ & 6,9 & 7,5 & 7,2 & 7,2 \\
\hline
\end{tabular}

Kualitas air pada penelitian ini yang diukur adalah suhu dan derajat keasaman $(\mathrm{pH})$. Data hasil pengukuran kualitas air dapat dilihat pada tabel 12. Suhu terendah didapati pada pengamatan diminggu ke tiga, hal tersebut dikarenakan terjadi setelah hujan turun, sedangkan suhu tertinggi didapati minggu ke 4, hal tersebut dikarenakan cuaca tengah terik dengan temperarur udara 300C. Data Hasil Pengamatan Kelangsungan Hidup disajikan pada Tabel 5.

Tabel 5. Pengamatan Kelangsungan Hidup Ikan Baung.

\begin{tabular}{lllllll}
\multirow{2}{*}{ Perlakuan } & \multicolumn{3}{c}{ Jumlah awal } & \multicolumn{3}{c}{ Jumlah akhir } \\
\cline { 2 - 7 } & U1 & U2 & U3 & U1 & U2 & U3 \\
\hline $\mathrm{P}_{0} \mathrm{~V}_{0}$ & 15 & 15 & 15 & 9 & 10 & 10 \\
$\mathrm{P}_{0} \mathrm{~V}_{1}$ & 15 & 15 & 15 & 10 & 9 & 10 \\
$\mathrm{P}_{0} \mathrm{~V}_{2}$ & 15 & 15 & 15 & 7 & 12 & 9 \\
$\mathrm{P}_{0} \mathrm{~V}_{3}$ & 15 & 15 & 15 & 11 & 10 & 9 \\
\hline
\end{tabular}

Angka kelulus hidupan benih ikan baung yang diporoleh selama pengamatan sebesar 64,4 - 66,6\%. Kelulushidupan ikan tersebut termasuk dalam kategori yang bervariasi antar perlakuan. Kematian ikan selama penelitian ini disebabkan oleh adanya organisme parasit sehingga menyebabkan luka pada beberapa bagian tubuh ikan yang menyebabkan luka pada beberpa bagian tubuh ikan yang menyebabkan ikan tersebut tidak semuanya mampu bertahan hidup pada saat minggu ke tiga dan minngu ke empat penelitian. Selain itu juga disebabkan karena kemampuan ikan beradaptasi dengan lingkungan tidak sama. Hal itulah yang menyebabkan kelulushidupan ikan menjadi bervariasi pada setiap perlakuan. Menurut Lakshmana dalam Armiah (2010) factor yang mempengaruhi tinggi rendahnya kelangsungan hidup adalah factor biotic antara lain competitor, kepadatan, populasi, umur, dan kemampuan organism beradaptasi terhadap lingkungan. Dalam budidaya, mortalitas merupaka penentu keberhasilan usaha dalam pemeliharaan.

\section{PEMBAHASAN}

\begin{tabular}{lcr} 
Pengaruh & Variasi & Azolla \\
microphylla & \multicolumn{2}{r}{ Terhadap } \\
Pertumbuan & panajng & Ikan \\
Baung & &
\end{tabular}

Pakan merupakan salah satu
faktor yang berperan dalam
pertumbuhan ikan baung. Semakin
tinggi kandungan nutrisi dalam pakan
maka semakin bagus pertumbuhan
ikan. Pertumbuhan panjang ikan
baung selama 30 hari pengamatan
yaitu pada perlakuan $\mathrm{P}_{0} \mathrm{~V}_{1}$ rerata
panjang semula $6,6 \mathrm{~cm}$ menjadi
$11,7 \mathrm{~cm}, \quad$ kemudian perlakuan
selanjutnya $\mathrm{P}_{0} \mathrm{~V}_{2}$ rerata panjang
semula $6,6 \mathrm{~cm}$ menjadi $12,7 \mathrm{~cm}$, dan


pada perlakuan $\mathrm{P}_{0} \mathrm{~V}_{3}$ rerata berat semula 6,6 menjadi $16,95 \mathrm{~cm}$. Pertumbuhan panjang ikan baung pada penelitian ini menunjukkan hasil tertinggi yaitu pada perlakuan $\mathrm{P}_{0} \mathrm{~V}_{3}$, diikuti dengan perlakuan $\mathrm{P}_{0} \mathrm{~V}_{1}, \mathrm{P}_{0} \mathrm{~V}_{2}$ dan terendah yaitu $\mathrm{P}_{0} \mathrm{~V}_{0}$ atau kontrol menunjukkan hasil rerata semula 6,6 $\mathrm{cm}$ menjadi $10,4 \mathrm{~cm}$. Tingginya pertambahan panjang pada perlakuan $\mathrm{P}_{0} \mathrm{~V}_{3}$. Hasil analisis ANOVA menunjukkan bahwa pemberian variasi Azolla microphylla pada pakan memberikan pengaruh nyata terhadap pajang ikan baung $(\mathrm{P}<0,05)$.

Hasil analisis menunjukkan masing-masing perlakuan secara garis besar memberikan perbedaan yang sangat nyata terhadap rerata pertambahan panjang ikan baung. Berdasarkan hasil uji lanjut menunjukkan pakan dengan perlakuan $\mathrm{P}_{0} \mathrm{~V}_{3}$ memberikan respon paling baik terhadap pertumbuhan panjang ikan baung.

Penambahan variasi Azolla yang berbeda mengakibatkan kadar persentase protein pada pakan berbeda-beda pula. Berdasarkan tabel 2 diketahui bahwa persentase kandungan protein pakan perlakuan $\mathrm{P}_{0} \mathrm{~V}_{3}$ menjadi perlakuan terbaik dengan penambahan variasi Azolla sebanyak 3000gr dapat mensuplai kandungan protein pada pakan sehingga total kandungan protein pada pakan mencapai 39,97\%. Sedangkan pada perlakuan P0V2 dengan penambahan variasi Azolla sebayak 2000gr pada pakan didapati persentase protein sebesar $35,41 \%$, kemuadian pada perlakuan P0V1 denagan penambahan variasi Azolla sebanyak 1000gr pada pakan didapati persentase protein sebesar $29,33 \%$, dan pada perlakuan P0V0 yaitu sebagai kontrol tanpa penambahan variasi Azolla di dapati persentase protein sebesar $23,85 \%$. Dengan adanya penambahan variasi tepung Azolla pada pakan menyebabkan perubahan nilai kandungan protein pada pakan, karena Azolla memiliki kandungan protein tinggi. Sehingga hal tersebut sangat mempengaruhi pertumbuhan ikan baung. Protein merupakan salah satu nutrisi yang sangat berpengaruh pada pertumbuhan ikan baung.

Protein merupakan zat gizi yang sangat diperlukan oleh ikan untuk pemeliharaan sel-sek tubuh, pembentukan jaringan, pergantian jaringan tubuh yang rusak, dan penambahan protein dtubuh dalam proses pertumbuhan. Protein juga digunakan sebgaai sumber energy apabila kebutuhan energi dari lemak dan karbohidrat tidak terpenuhi. Ketersediaan protein pada pakan amat sangat mempengaruhi pertumbuhan ikan, baik pertumbuhan panjang maupun pertumbuhan bobot. Hal ini diperkuat oleh Sukadi (2003) baik tidaknya suatu pakan ditentukan oleh kandungan nutrisinya. Salah satu kebutuhan nutrisi yang penting untuk ikan adalah protein, sehingga kekurangan protein dalam pakan akan dapat menyebabkan terhambatnya pertumbuhan.

Berdasarkan Tabel 16 dapat dilihat adanya kecenderungan bahwa semakin besar dosis Azolla yang diberikan maka menghasilkan pertambahan bobot yang besar pula. $\mathrm{P}_{0} \mathrm{~V}_{3}$ dengan penambahan variasi Azolla sebanyak 3000gr menjadi perlakuan yang memberi pengaruh terbaik pada pertumbuhan bobot ikan baung. Dengan itu diketahui bahwa ikan membutuhkan energi dari makanan yang dikonsumsinya untuk proses perawatan tubuh maupun untuk aktivitas fisik, tumbuh dan bereproduksi. Oleh karena itu haruslah ada keseimbangan antara pasok energi dengan penggunaannya (Affandi $d k k$, 1992). Hal ini menunjukkan bahwa bahan pakan tanpa nutrisi yang cukup 
hanya dapat digunakan untuk pemeliharaan tubuh saja. Sedangkan kelebihannya yang digunakan untuk pertumbuhan hanya sedikit . Menurut Affandi dkk 1992 dalam Komariyah(2010:15), energi yang digunakan untuk metabolism harus dipenuhi dahulu, selanjutnya untuk pertumbuhan. Histogram rerata pertambahan panjang hewan uji disajikan pada Gambar 1 dibawah ini.

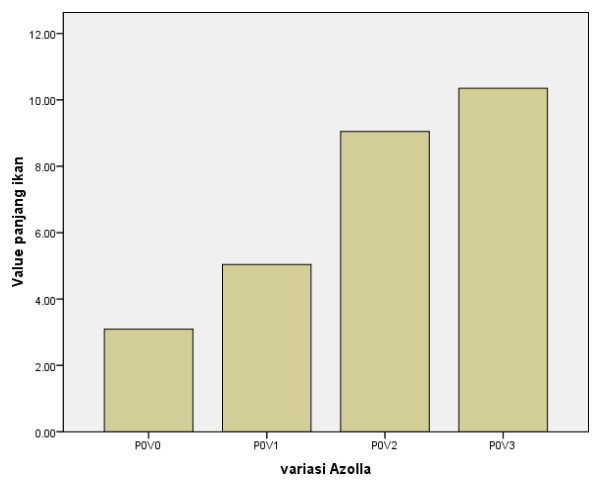

Gambar 1. Histogram Pertambahan panjang Ikan Baung

Wicaksono dkk, (2018) dalam penelitiannya pemberian tepung Azolla pinnata pada pakan secara berturut-turut dari kadar 10\% hingga $40 \%$ dapat semakin meningkatkan laju pertumbuhan panjang ikan bandeng, Pertumbuhan panjang ikan bandeng yang Tertinggi rata-rata pertumbuhan panjang ikan sebesar $1.29 \mathrm{~cm}$ pada dosis Azolla $40 \%$ berbeda secara signifikan dengan empat perlakuan lainnya. Sedangkan penelitian Kristiawan dkk, (2017) panjang tubuh rata-rata ikan sidat yang terbaik selama penelitian terdapat pada perlakuan PA4 yaitu penambahan dosis Azolla pada pakan sebesar 30\% memberikan pengaruh pada pertumbuhan panjang tubuh Ikan sidat berkisar 22,3-28,2 g menjadi 23,6$28,4 \mathrm{~cm}$. hal ini menunjukkan bahwa penambahan variasi Azolla pada pakan dapat membrikan pengaruh terhadap pertumbuhan panjang ikan.

\section{Pengaruh Variasi Azolla microphylla Terhadap Pertumbuan bobot Ikan Baung}

Pertumbuhan merupakan proses bertambahnya panjang serta berat suatu organisme, yang dapat dilihat dari perubahan ukuran panjang dan berat dalam satuan waktu. Pertumbuhan sangat dipengaruhi oleh Faktor internal dan Faktor eksternal. Faktor internal merupakan Faktor yang berhubungan dengan kondisi ikan itu sendiri seperti umur dan sifat genetiknya seperti keturunan, kemmapuan memanfaatkan pakan serta ketahanan terhadap suatu serangan penyakit. Huet 1971 dalam Komariah (2010:12) menyatakan, Faktor eksternal merupakan Faktor yang berasal dari luar yang meliputi lingkungan fisiks maupun kimia air, ruang gerak yang diperlukan, persaingan dan ketersediaan pakan yang baik secara kuantitas maupun kualitas.

Selama pemeliharaan, terjadi pertumbuhan yakni perubahan berat ikan baung. Perubahan rata-rata berat pada perlakuan V0P1 yaitu dari $6,2 \mathrm{gr}$ menjadi 16,3. Angka rerata ini masih lebih besar jika di bandingkan dengan kontrol atau P0V0 yaitu dari $6,2 \mathrm{gr}$ menjadi 11,75. Begitupun dengan perlakuan P0V2 dengan rerata berat semula 6,2gr menjadi 19,2gr dan perlakuan P0V3 rerata berat semula 6,3 menjadi 27,4gr. Kontrol atau P0V0 menjadi rerata terendah dibandingkan dengan seluruh perlakuan. Sedangkan Pertumbuhan berat ikan baung terbaik pada perlakuan P0V3.

Hasil analisis ANOVA menunjukkan bahwa pemberian variasi Azolla microphylla pada pakan memberikan pengaruh nyata terhadap berat ikan baung $(\mathrm{P}<0,05)$. Hasil analisis menunjukkan masingmasing perlakuan secara garis besar 
memberikan perbedaan yang sangat nyata terhadap rerata pertambahan bobot biomassa ikan baung. Berdasarkan hasil uji lanjut menunjukkan pakan dengan perlakuan $\mathrm{P}_{0} \mathrm{~V}_{3}$ memberikan respon paling baik terhadap pertumbuhan bobot ikan baung. Penambahan variasi Azolla yang bebeda-beda mengakibatkan penambahan bobot ikan baung yang berbeda pula.

Penambahan variasi Azolla yang berbeda mengakibatkan kadar persentase protein pada pakan berbeda-beda pula. Berdasarkan tabel 2 diketahui bahwa persentase kandungan protein pakan perlakuan $\mathrm{P}_{0} \mathrm{~V}_{3}$ menjadi perlakuan terbaik dengan penambahan variasi Azolla sebanyak 3000gr dapat mensuplai kandungan protein pada pakan sehingga total kandungan protein pada pakan mencapai 39,97\%. Sedangkan pada perlakuan P0V2 dengan penambahan variasi Azolla sebayak 2000gr pada pakan didapati persentase protein sebesar $35,41 \%$, kemuadian pada perlakuan P0V1 denagan penambahan variasi Azolla sebanyak 1000gr pada pakan didapati persentase protein sebesar $29,33 \%$, dan pada perlakuan P0V0 yaitu sebagai kontrol tanpa penambahan variasi Azolla di dapati persentase protein sebesar $23,85 \%$. Dengan adanya penambahan variasi tepung Azolla pada pakan menyebabkan perubahan nilai kandungan protein pada pakan, karena Azolla memiliki kandungan protein tinggi. Sehingga hal tersebut sangat mempengaruhi pertumbuhan ikan baung. Protein merupakan salah satu nutrisi yang sangat berpengaruh pada pertumbuhan ikan baung.

Protein merupakan zat gizi yang sangat diperlukan oleh ikan untuk pemeliharaan sel-sek tubuh, pembentukan jaringan, pergantian jaringan tubuh yang rusak, dan penambahan protein dtubuh dalam proses pertumbuhan. Protein juga digunakan sebgaai sumber energy apabila kebutuhan energi dari lemak dan karbohidrat tidak terpenuhi. Ketersediaan protein pada pakan amat sangat mempengaruhi pertumbuhan ikan, baik pertumbuhan panjang maupun pertumbuhan bobot. Hal ini diperkuat oleh Sukadi (2003) baik tidaknya suatu pakan ditentukan oleh kandungan nutrisinya. Salah satu kebutuhan nutrisi yang penting untuk ikan adalah protein, sehingga kekurangan protein dalam pakan akan dapat menyebabkan terhambatnya pertumbuhan.

Berdasarkan Tabel 16 dapat dilihat adanya kecenderungan bahwa semakin besar dosis Azolla yang diberikan maka menghasilkan pertambahan bobot yang besar pula. $\mathrm{P}_{0} \mathrm{~V}_{3}$ dengan penambahan variasi Azolla sebanyak $3000 \mathrm{gr}$ menjadi perlakuan yang memberi pengaruh terbaik pada pertumbuhan bobot ikan baung. Dengan itu diketahui bahwa ikan membutuhkan energi dari makanan yang dikonsumsinya untuk proses perawatan tubuh maupun untuk aktivitas fisik, tumbuh dan bereproduksi. Oleh karena itu haruslah ada keseimbangan antara pasok energi dengan penggunaannya (Affandi $d k k$, 1992). Hal ini menunjukkan bahwa bahan pakan tanpa nutrisi yang cukup hanya dapat digunakan untuk pemeliharaan tubuh saja. Sedangkan kelebihannya yang digunakan untuk pertumbuhan hanya sedikit . Menurut Affandi $\quad d k k 1992$ dalam Komariyah (2010:15), energi yang digunakan untuk metabolism harus dipenuhi dahulu, selanjutnya untuk pertumbuhan. Berikut histogram pertumbuhan bobot ikan baung pada Gambar 2 di bawah ini. 


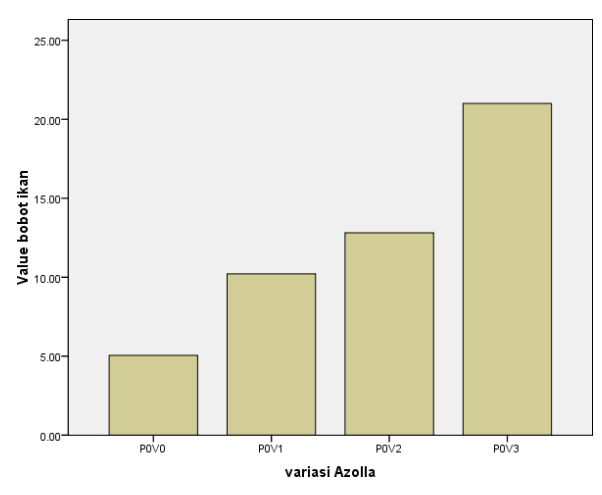

Gambar 2. Histogram Pertambahan bobot Ikan Baung

Penelitian oleh Komariyah dkk,(2010) didapati perlakuan dan dosisi terbaik dengan penambahan dosis Azolla sp 8\% dari bobot ikan menghasilkan pertambahan bobot rerata terbaik bandingkan dengan perlakuan lainnya dengan pertumbuhan rerata 2,8100gr. Sedangkan penlitian oleh Suhenda, dkk, (2010), Hasil penelitian menunjukkan Pakan dengan kadar protein $31 \%$ memberikan laju pertumbuhan spesifik $(2,67 \%)$ lebih tinggi dibandingkan dengan kadar protein $27 \%$. Hal tersebut di perkuat oleh Cherryl (2014) dan Kathirvelan (2015), hasil analisis kimia mengindikasikan daun Azolla microphylla yang telah dikeringkan dapat menjadi sumber protein alami yang potensial sebagai bahan pakan non konvensional yang rendah kandungan lignin (Cherryl, 2014; Kathirvelan, 2015).

\section{Kelulushidupan Ikan Baung}

Persentase kelangsungan hidup ikan baung selama penelitian mencapai $64 \%$. Nilai kelangsungan hidup ini mengalami penurunan jika dibandingkan dengan hasil penelitian Supartoto, et al. (2014), dimana substitusi sebagian pelet dengan Azolla tidak berpengaruh terhadap sintasi (kelangsungan hidup) ikan nila merah hingga umur 60 hari, dimana tingkat kelangsungan hidup ikan nila merah yang diberi pakan pelet dengan substitusi Azolla mencapai diatas $90 \%$ pada semua perlakuan (kategori baik). Alikunthi et al., dalam Sulastri (2006) menyebutkan bahwa kelulushidupan lebih dari 50\% tergolong baik; 30-50\% tergolong sedang; kurang dari $30 \%$ tergolong rendah. Perdana et al. (2016) mengemukakan bahwa tingkat kelangsungan hidup tidak dipengaruhi secara langsung oleh pakan, tetapi dipengaruhi oleh faktor biotik dan abiotik. Faktor biotik terdiri dari umur dan kemampuan ikan dalam menyesuaikan diri dengan lingkungan tempat hidup. Faktor abiotik antara lain ketersediaan makanan dan kualitas media hidup.

\section{Kualitas Air}

Faktor eksternal yang dapat mempengaruhi pertumbuhan dan kelulushidupan ikan uji ialah air sebagai media hidupnya. Suhu yang didapat selama penelitian berkisar $28,65-29,5^{\circ} \mathrm{C}$. Suhu teredah biasanya didapat setelah hujan turun dan suhu tertinggi terjadi apabila kondisi cuaca tengah terik matahari. Sedangkan $\mathrm{pH}$ yang didapat selama penelitian berkisar 6,9-7,2. Data kualitas air yang diperoleh selama penelitian termasuk baik bagi kehidupan ikan baung karena angka tersebut memenuhi nilai standar pengukuran oleh Amri dan Khairuman (2010).

Perbedaan suhu terjadi karena adanya perbedaan suhu antara pagi, siang, sore dan malam hari. Keadaan suhu yang seperti ini masih tergolong sesuai untuk kelulushidupan ikan baung. Perbedaan suhu ini disebabkan karena pengaruh intensitas cahaya matahari yang mengenai perairan. Sesuai dengan pendapat Syafriadiman (2005), bahwa suhu pada siang hari dipengaruhi oleh jumlah sinaran matahari yang masuk ke perairan, 
sementara pada malam hari dipengaruhi oleh panas yang tersimpan di dalam air. Kisaran suhu air selama penelitian ini dianggap sangat baik sesuai dengan pendapat Boyd dalam Agusnimar dan Rosyadi (2013) dimana kisaran suhu di daerah tropis antara $25-32^{\circ} \mathrm{C}$, masih layak untuk kelulushidupan dan pertumbuhan organisme akuantik.

\section{Sumber Belajar Biologi}

Suatu proses belajar khususnya dalam pemanfaatan sumber belajar, guru mempunyai tanggung jawab membantu peserta didik belajar agar lebih mudah, lebih lancar, lebih terarah. Oleh sebab itu guru dituntut untuk memiliki kemampuan khusus yang berhubungan dengan pemanfaatan sumber belajar. Sumber belajar mempunyai peran yang sangat erat digunakan dengan pembelajaran yang dilakukan, dan pola-pola yang dilakukan oleh guru. Karwono dan Mularsih (2010:140) Sumber belajar adalah segala sesuatu yang dimanfaatkan oleh seseorang mempelajari sesuatu. Sumber belajar meliputi: pesan, orang, bahan, alat, teknik, dan latar. Sumber belajar dapat dibedakan menjadi sumber belajar yang didesain dan sumber belajar yang dimanfaatkan.

Pemanfaatan sumber belajar, guru mempunyai tanggung jawab membantu peserta didik belajar agar lebih mudah, lebih lancar, lebih terarah. Guru dituntut untuk memiliki kemampuan khusus yang berhubungan dengan pemanfaatan sumber belajar. Sumber belajar yang beraneka ragam di sekitar kehidupan peserta didik, baik yang didesain maupun yang non desain belum dimanfaatkan secara optimal dalam pembelajaran. Muhfahroyin (2009:25) Pengalaman belajar di kelas dapat diperoleh dengan jalan mengadakan interaksi antara siswa dengan objek dan sumber belajar sesuai dengan uraian materi pembelajaran yang telah dirumuskan. Bentuknya dapat berupa telaah buku, telaah hasil penelitian, mengadakan percobaan di laboratorium, mengukur panjang sel dengan menggunakan penggaris melalui mikroskop, presentasi kelompok setelah melakukan percobaan dan lainnya.

Pengembangan kemampuan siswa dalam berpikir kritis memerlukan adanya sumber belajar yang dikembangkan oleh guru. Salah satu sumber belajar tersebut adalah panduan praktikum. Praktikum memegang peranan yang penting dalam proses pembelajaran IPA khusus nya Biologi. Prayitno (2017:31) Petunjuk praktikum merupakan sumber yang memuat topik prakikum, tujuan praktikum, dasardasar teori, alat dan bahan praktikum, prosedur kerja praktikum, lembar hasil pengamatan praktikum dan evaluasi yang disusun atas dasar tujuan praktikum yang ada. Dengan demikian panduan praktikum merupakan suatu buku yang berisi pengarahan yang bertujuan untuk memberi petunjuk dalam melakukan kegiatan praktikum.

\section{KESIMPULAN}

Berdasarkan penelitian yang dilakukan terhadap pemberian variasi Azolla pada pakan terhadap pertumbuhan ikan baung dapat disimpulkan sebagai berikut: Berdasarkan penelitian yang dilakukan terhadap pemberian variasi Azolla pada pakan terhadap pertumbuhan ikan baung dapat disimpulkan sebagai berikut: 1) Pemberian variasi Azolla berpengaruh tehadap pertumbuhan bobot ikan baung. Bersasarkan hasil analisi nilai sig. $0,000<0,05$ yang berarti penambahan variasi Azolla dengan dosis berbeda berpengaruh terhadap pertumbuhan bobot ikanbaung; 2) Pemberian variasi Azolla berpengaruh tehadap 
pertumbuhan panjang ikan baung. Berdasarkan hasil analisi nilai sig. $0,000<0,05$ yang berarti penambahan variasi Azolla dengan dosis berbeda berpengaruh terhadap pertumbuhan panjang ikanbaung; 3) Variasi penambahan Azolla menyebabkan pertumbuhan bobot yang berbedabeda. Pertumbuhan bobot terbaik pada perlakuan $\mathrm{P}_{0} \mathrm{~V}_{3}$ dengan penambahan variasi Azolla sebanyak 3000g yaitu $27,4 \mathrm{~g}$ danterendah pada perlakuan $\mathrm{P}_{0} \mathrm{~V}_{0}$ tidak ada penambahan Azolla yaitu $11,75 \mathrm{~g}$; 4) Variasi penambahan Azolla menyebabkan pertumbuhan panjang yang berbeda-beda. Pertumbuhan panjang yang terbaik pada perlakuan $\quad \mathrm{P}_{0} \mathrm{~V}_{3}$ denganpenambahan variasi Azolla sebanyak $3000 \mathrm{~g}$ yaitu $16,95 \mathrm{~cm}$ dan terendah pada perlakuan $\mathrm{P}_{0} \mathrm{~V}_{0}$ tidak ada penambahan Azolla yaitu 10,4cm; 5) Kelulushidupan ikan baung selama 30 hari pengamatan mencapai64,4 $66,6 \%$; 6) Kualitas air selama penelitian seperti suhu berkisar $28,65^{\circ} \mathrm{C}-29,5^{\circ} \mathrm{C}, \mathrm{pH} 6,9-7,2$.

\section{DAFTAR RUJUKAN}

Agusnimar dan Rosyadi. 2013. Pengaruh Kombinasi Pakan Alami dan Buatan Terhadap Kelulushidupan dan Pertumbuhan Ikan Selais (Kryptopterus lais). Jurnal Dinamika Pertanian. Vol. XXVIII. (3): 255-264.

Amri, K., \& Khairuman. (2010). Ikan baung, peluang usaha dan teknik budidaya intensif. PT Gramedia Pustaka Utama. Jakarta. 88 hal.

Armiah, J. 2010. Pemanfaatan Fermentasi Ampas Tahu Dalam Pakan Terhadap Pertumbuhan Benih Ikan Selais
(Ompokhypopyhalmus). Skripsi Fakultas Perikanan Dan Ilmu Kalautan Universitas Riau. Pekanbaru. (tidak diterbitkan).

Haetami, 2005. Tingkat Penggunaan Gulma Air Azolla Pinata dalam Ramsum terhadap Pertumbuhan dan Konversi Pakan Ikan Bawal Air Tawar. Universitas Padjajaran. Bandung.

Haetami, K dan Sastrawibawa, 2005.

Evaluasi Kecernaan Tepung Azolla dalam Ransum Ikan Bawal Air Tawar (Colossoma macropomum). Jurnal Bionatura, 7, (3),: 225233.

Haetami, K dan Sastrawibawa, 2005. Evaluasi Kecernaan Tepung Azolla dalam Ransum Ikan Bawal Air Tawar (Colossoma macropomum). Jurnal Bionatura, 7, (3),: 225 - 233.

Karwono dan Heni, Mularsih. 2009. Belajar dan Pembelajaran Serta Pemanfaatan Sumber Belajar. Ciputat: Cerdas Jaya. Ketiga. Rajawali Pers: Jakarta.

Khan, M.S., K.J. Ang, M.A. Ambak \&

C.R. Saad. (1993). Optimum dietary protein requirement of a Malaysian catfish, Mystus nemurus. Aquaculture, 112: 227- 235.

Komariyah,. Pranggono, H. Prasetyo, A.A. 2010. Pengaruh Pemberian Tepung Azolla sp Dengan Dosis Berbeda Terhadap Pertumbuhan Benih Ikan Gift ( Oreohromis sp). Universitas Pekalongan. 
Kumari, R. (et all). 2018. Chemical composition and pellet quality of Azolla pinnata grown in semi-arid zone of India. International Journal of Chemical Studies 2018; 6(3): 2031-203.

Muhfahroyin. 2009. Telaah Biologi SMP. Metro: Lemlit UM Metro Press.

NRC. 1993. Nutrient Requeirements of Warmwater Fish and Shell Fish. Revised Edition. National Academy Press. Washington D.C. $102 \mathrm{p}$.

Prayitno, Trio Ageng. 2017.

\begin{tabular}{|c|c|}
\hline Pengembangan & Petunjuk \\
\hline Praktikum & Mikrobiologi \\
\hline Program & Pendidikan \\
\hline Biologi. J & ota. Vol.3, \\
\hline No. 1. Edisi & Iuari 2017. \\
\hline
\end{tabular}

Suhenda, N. Samsudin, R. Nugroho, $\quad$ E. 2010. Pertumbuhan Benih Ikan Baung (Hemibagrus Nemurus) Dalam Keramba Jaring Apung Yang Diberi Pakan Buatan Dengan Kadar Protein
Berbeda. Jurnal Iktiologi Indonesia, 10(1): 65-71, 2010

Sulastri, T. 2006. Pengaruh Pemberian Pakan Pasta dengan Penambahan Lemak yang Berbeda Terhadap Pertumbuhan dan Kelulushidupan Benih Ikan Selais (Kryptopterus lais). Skripsi. Fakultas Pertanian Jurusan Perikanan Universitas Islam Riau, Pekanbaru. 59 halaman (tidak diterbitkan).

Supartoto, P. Widyasunu, Rusdiyanto, M. Santoso. 2012. Eksplorasi potensi Azolla microphylla dan Lemna polyrhizza sebagai produsen biomas bahan pupuk hijau, pakan itik dan ikan. prosiding seminar nasional pengembangan sumber daya pedesaan dan kearifan lokal berkelanjutan II, 27-28 Nopember, Purwokerto Indonesia, hal 7-225.

Syafriadiman., N. A. Pamungkas dan Saberina. 2005. Prinsip Dasar Pengelolaan Kualitas Air. Mina Mandiri. $\quad$ Pekanbaru. 132 halaman. 